\title{
TRIAL FOR EVALUATION OF VARIOUS PARTICIPATION METHODS
}

\author{
大坂谷吉行 \\ キーワード \\ 市民参加手法，評価の試み，評価の視点，評価基準，評価方法 \\ Keywords : \\ Participation method, Trial of evaluation, Evaluation point, Evaluation \\ criteria, Evaluation system
}

\section{Yoshiyuki OSAKAYA — $* 1$}

There are various methods for citizens' participation such as committee, symposium, public meeting, public hearing, questionnaire, workshop and others in plan making process or plan decision process. Various methods in Muroran City after 1991 were analyzed their contents and were tried to evaluate on the basis of 10 evaluation points considered to activate participation. As the result of total evaluation, workshop was given higher score than other methods. Although the trial of evaluation was done by only the author of this study, it means individual differences among several persons were rejected and all methods were evaluated by the same criteria.

\section{1. 研究の背景と目的}

1992 年の都市計画法の改正により，「市町村の都市計画に関する 基本的な方針」(同法第 18 条の 2)が創設され，住民の意見を反映し て定めるとされている。法定都市計画ではない計画，例之ば，都市 景観の計画においては，各種市民参加手法が先取りして用いられて いる。1985 年に浦口と大坂谷 (文献 1) は，「住民参加による景観調 査・計画の試み」と題して，イベント型の調査と合意形成型の計画 立案の特徴, 実施上のポイント, 具体例について述べ, ワークショッ プにも言及している。また，行政改革の中で，都市計画の地方分権 の流れが基調としてあり，都市計画をより市民本位で個性的なもの にしていく前提条件は，市民参加と情報公開であると考えられる。 情報公開は，行政が情報を独占しないで，行政，市民，専門家が情 報を共有することに意義がある。例えば，まちづくりに関わる各種 情報が公開されていないと，市民グループが代替案を作成すること は極めて困難と言えよう。そして，今後，都市計画の様々な場にお いて，市民参加が求められていくと思われる。

本論文では，ある特定の地区の計画や事業に直接的に関わる限定 された利害者（住民や企業等）の参加を「住民参加」と定義する。 また，限定された利害者だけではなく，幅広い市民（企業や団体を 含む）の参加を「市民参加」と定義する。従って「住民参加」は, 「市民参加」の部分集合と言える。

他方，具体的な市民参加の手法は，多種多様である。既住研究を 見ても，例之ば，吉村輝彦ほか (文献 2) では, 川崎市宮前区の区づ くりプランの策定を事例として, 公募による策定委員会と地区部会, 自由な直接参加の場としての「まちづくり広場」, 間接参加としての 文書の他, ワークショップ, シンポジウムの手法が用いられている。 また，村木美貴ほか（文献 3）では「まちづくり協議会」が，錦澤滋 雄浪（文献 4) では「ワークショップ」が，梖枝潤一ほか（文献 5) では「環境シミュレーション」が住民とのコミュニケーションの道 具として用いられている。

しかし，多くの既住研究は，各研究論文の著者が関与した「ある 特定の計画づくり」で用いられた市民参加の手法について言及して いるが，同計画づくりの内容やプロセスが主たる考察の対象である
ことから，用いられた手法による成果を評価していても，手法その ものを評価していない。また，各種手法を統一的に評価しようとす ることを試みた既住研究は見られない。これは，定性的な評価はあ る程度可能であっても，定量的な評価は非常に困難と考えられてい るためと思われる。

その理由は，狭い意味では市民参加の手法とは言えないアンケー ト調查であっても，設問を工夫し，自由記入意見を尊重すれば，市 民の意見を汲み上げられるし，説明会や公聴会も行政側が市民に一 方的に説明するだけでなく，自由な意見交換の時間を確保すれば， 行政＼cjkstart市民という一方向の流れから，双方向の流れに変えることが できるからである。即ち, 同じ手法であっても, やり方次第で, 評 価が異なることが定量的な評価を困難にしていると考えられる。

また, 市民参加手法を評価しようとすれば, 説明会やワークショッ プ等に評価者が実際に参加していなければ，その場の雾囲気や具体 的な意見交換を知ることが困難であるため，評価できない。ワーク ショップで出た全ての意見（提案を含む）が，報告書に参考資料と して揭載されていても，それだけを見て評価することは危険である。 評価者自身が参加していない市民参加手法を評価することは，あま ク意味がない。従って，市民参加手法を評価する場合には，評価者 自身が参加したものだけを評価せざるを得ない。即ち, ある評価者 が参加した各種市民参加手法を相対的に評価することになり，主観 的な評価にならざるを得ない。しかし，いくつかの評価の視点を設 けて，視点毎に評価基準を定めれば，評価者が異なっても，その評 価者が参加した各種市民参加手法に限定すれば，それらを相対的に 評価することは可能であると考えられる。

本研究は, 室蘭市のまちづくりの計画や都市景観形成基本計画等 に直接的あるいは間接的に参加した立場から，各種計画や各種活動 で用いられた市民参加手法の実態を考察するとともに各種手法の評 価の視点を設定し, 視点毎に評価の基準を定めて, 筆者が参加した 各種手法の統一的な評価を試みることを目的としている。

また, 本研究は, 各種計画や各種活動で用いられている市民参加 手法の問題点や評価結果を示すことを通してて, 各種手法をより実質 的な参加手法に改善していくことに役立つと考える。 


\section{2. 市民参加の意義と手法}

（1）市民参加の意義

市民参加のまちづくりを実践するにあたり，筆者は市民参加の意 義を市民，行政，フォーラム等の主催者に以下のように説明した。

(1) 専門家以外の幅広い意見を取り込める。

(2) まちの実情を市民によく理解してもらえる。

(3) 参加自体が学習の場になる。参加経験の蓄積が重要である。

(4) まちづくりに対する責任を自覚する。まちづくりの主役は市 民であることを強調して, 従来の陳情型行政や行政依存体質か ら脱却して, 主体的な参加により, 市民, 行政, 専門家の役割 分担が明確になる。

(5) 計画段階からの参加で，事業等がスムーズに進む。

（2）市民参加手法の評価の視点

市民参加の各種手法は，多種多様であり，また，同じ手法であっ ても，やり方次第で効果的になったり，効果的でなくなったりする ことがある。従って, 単純に参加者の数とか, 意見紷数等で, 各種 手法を定量的に評価することはむずかしい。しかし，筆者は，定性 的には，以下に示したような評価の視点があると考える。

(1) 幅広い意見を取り込み

市民参加の大きな意義である「幅広い意見を取り込むこと」 ができたか，否か。

(2) 参加者が限定されているか, 否か。

(1)の「幅広い意見」と関連するが，参加者の年代，性別，職 業等が限定されると，市民各層の意見を取り込めないと考えら れる。しかし, シンポジウム等のテーマ等によっては, 参加者 を限定，あるいは意困的に絞り込んだ方がよい場合がある。

(3) 一方向の流れか, 双方向の流れか。

行政, 主催者, 講演者等が, 説明や話をして参加者が聴くだ けという一方向の流れか，意見交換の時間を十分にとって双方 向の流れにしているか。文化行事的な講演会では，参加者が聴 くだけも止むを得ないが，まちづくりの講演会では意見交換の 時間を十分にとるべきと考える。

(4) 配布資料や説明が参加者にわかりやすいか。 市民参加の意義「まちの実情を市民によく理解してもらう」 と関連して，参加者がわかりやすいように工夫した資料を配布 し，わかりやすく説明することが重要であると考之る。

(5) 継続性があるか, 否か。 市民参加の意義「参加経験の蓄積が重要」と関連で, 1 回限り (単発)の開催ではなく, 継続性（連続性）があるか。委員会や 審議会等は数回開催されるのが一般的であるが, ワークショッ プやフォーラム等は, 単発で終らせずに継続することで,「問題 の発見 $\rightarrow$ 課題の整理 $\rightarrow$ 改善の提案 $\rightarrow$ 計画づくり」というように 内容を梁めることが期待される。

(6) 出された市民の意見の取り报いが明確か。

ワークショップや文書で出された市民の意見の取り扱いが明 らかにされており，主催者（特に行政）に都合のよい部分だけ

の「つまみ食い」になっていないか。

(7) 市民が発言する時間が十分に確保されているか。 (3)と関連するが，市民と行政（あるいは主催者や専門家）と の情報の流れを双方向の流れにするためには，市民が発言する
時間を十分に確保する必要がある。現実には，申し訳程度に最 後に 1 人〜 2 人の質問を受ける事例が少なくない。

(8) 能動的な参加か, 受動的な参加か。

参加手法を評価する場合, 市民の主体的な参加に高い評俩が 与えられるべきと考える。参加形態が能動的か, 受動的かで判 断が分かれる。ワークショップは能動的な参加であり, 説明会 は説明の後に意見交換の時間をとっても受動的な参加である。

(9) 主催者が市民参加に積極的か，消極的か。

同じ参加手法であっても，主催者の姿勢や態度が市民参加に 樍極的か，消極的かで評価が分かれる。建前は別にしても主催 者の本音が消極的な場合, 同じ参加手法であっても, 効果が薄 れてしまう。

(10) 形式的に行われていないか。

特に法律や条例に基づく参加手法の場合，単なる行政手続き の一部になり, 形骸化していないか。

(3) 市民参加の手法

筆者が都市計画，都市景観等に関係した各種計画づくり，各種委 員会, フォーラムやシンポジウム等に参加した事例で, 用いられた 市民参加の手法を，以下のように分類した。

A．行政が主体となった参加手法

$A-1$. 公聴会（法定都市計画に関わるもの）

$A-2$. 説明会

$\mathrm{A}-3$ 。郵便, FAX, 電子メールによる意見聴取

$\mathrm{A}-4$. ヒアリング

$A-5$.アンケート調查

$\mathrm{A}-6$. 行政の各種審議会や委員会に市民が参加（委員公募）

B．学習を主体とした参加手法

B-1．講演会

B-2.シンポジウム（フォーラム）

B-3．タウンウォッチング (見学会)

C . 住民主体の参加手法（地区レベル）

$\mathrm{C}-1$. まちづくり委貝会・協議会・研究会 ※

$\mathrm{C}-2$ ．ワークショップ（地区限定型）

$\mathrm{C}-3$. 計画づくり

D. 市民主体の参加手法（全市レベル）

D-1. まちづくり委員会・協議会・研究会 ※

D-2．ワークショップ（テーマ限定型）

$\mathrm{D}-3$. 計画づくり

※行政主導のものは除く

\section{3 、各種市民参加手法の実態と問題点}

A. 行政が主体となった参加手法

A-1．公聴会（法定都市計画に関わるもの）

1998 年 4 月 22 日に北海道都市計画課は, 室蘭圈都市計画市街化 区域及び市街化調整区域の区域区分（線引き）の変更に伴う公聴会 を室蘭市で開催した。公聴会は変更案に住民が意見を述べる機会で あるが, 知事指名の公述人 2 名が意見を述べたにすぎない。また, 知 事指名の公述人の発言時間は 20 分程度，一般公述人の発言時間は 10 分程度に制限されている。この公聴会は都市計画法第 16 条に定 められた「都市計画の決定及び変更」の行政手続きの一部である。 
質問を受けないこと, 発言時間の制限, 要旨を書面で事前に届け出 ることを考えれば，住民の意見を積極的に汲み上げるとは言えない。 $A-2$ ．説明会

(1) 1995 年 3 月に「室蘭地域商業近代化計画報告書」が完成し, 同 年 5 月に輪西地区, 本輪西地区, 中央地区, 東地区, 中島地区でそ の説明会が開催された。説明者は 2 人で, 筆者はその 1 人であっ た。同計画の策定では，地区毎に地区分科会を設置し，10人程度 の商業者が参加した。地区分科会のメンバー以外の商業者や一般 住民に新しい「商業近代化計画」の内容を知ってもらうことを目 的として，各地区で説明会を行った。概ね，1時間を説明にあて， 残り1時間を質疑応答にあてた。

(2) 1997 年 4 月に新しい「北海道長期計画」の説明会が室蘭市内で 開催された。同計画の概要の説明の後に 30 分程度の質疑応答の時 間があった。長期計画の策定にあたって北海道内各地でこうし た説明会が行われることは以前になかったので，1 歩前進と言え るが, 各支庁所在地で 1 回だけの開催であり, 参加者が意見を述べ る時間が不十分であり，形骸化している。

(3) 1997 年 5 月に新しい「室蘭市総合計画」の基本構想の説明会が 蘭西 (室蘭駅中心) と蘭東 (東室蘭駅中心) で行われた。前の「室 闌市総合計画」の策定の際には説明会は行われず,これも1歩前進 と言える。説明後の 1 時間程度を質疑応答や自由意見にあててい た。発言する人が多く，活発な印象を受けたが，時間不足で打ち 切りというのは納得がいかない。1997年 10 月に「室蘭市総合計 画」の基本計画の説明会が蘭西と蘭東で開催され,「JR 室蘭本線東 室蘭駅付近の鉄道高架事業を盛り込むか，否か」が大きな争点と なったこともあり，いろいろな意見が相次いだが，時間不足で打 ち切りとなった。 5 月の基本構想, 10 月の基本計画の両方について 言えることは，参加者からの意見の取り扱いが不明確である。こ れでは行政に都合良い部分だけを「つまみ食い」することになる。 $A-3$ 。郵便，FAX，電子メールによる意見聴取

室蘭市総合計画の策定作業では, 市の広報誌や上述の説明会の配 布資料で，同計画に対する意見を FAX または電子メールで受け付 けることが記載されていた。電話は不可で，郵便による意見も受け 付けていたが，市民からの意見の取り扱いが不明確，不明朗であっ た。市民からの意見を整理し，公表すべきである。

$\mathrm{A}-4$ ．ヒアリング

「商業近代化計画」の策定作業に先立って，筆者らは 1993 年 11 月 に各地区の商店街の問題点や課題を把握するために輪西地区, 中央 地区，本輪西地区，東地区，中島地区の順にヒアリングを行った。 後日, 問題点や課題を整理した文書を各地区に配布, 公表した。 $\mathrm{A}-5$. アンケート調查

室蘭市の都市景観形成基本計画策定の一連の調查の中で「都市景 観市民意識調查」が行われ，商業近代化計画を策定する際に「消費 者動向調查」や「来街者調查」が行われた。最後の「来街者調查」 のみは，街頭におけるアンケート調査であるが，ほかの二つは郵送 によるアンケート調査である。アンケート調查も，回答を通して参 加するという意味で，広義の参加の形態と言之る。しかし，基本的 には市民の意識やニーズの把握に主眼が置かれている。ただし，ア ンケート用紙の最後にある自由記入欄にいろいろな意見が書かれて いて，かつ，調查の実施者側がそれらの意見を積極的に汲み上げよ
うと努力すれば，ある程度は使える手法と言えよう。 A-6. 行政の各種審議会や委員会に市民が参加（公募）

室蘭市都市景観市民愁話会のメンバーの一部を市の広報誌を通じ て, 初めて公募した。これを契機として, 各種審議会や各種委員会 の委員の一部を公募するようになった。しかし, 公募委員は審議会 や委員会の定員の 2 割未満という現状にある。今後, 公募に応じた人 数が多い場合に人選をどうするのか, 他市で見られるように委員全 員を公募にするのか，ということが課題である。審議会や委員会は， 事務局が資料（原案等）を説明し，それを聴いた後に委員が意見を 述べる形式が大半なので, 公募委員が加わったとしても, 行政サイ ドー市民サイドという情報の流れとなり，市民参加としては受動的 な参加形態と言える。

\section{B ．学習を主体とした参加手法}

\section{B - 1 . 講演会}

1997 年 10 月の講演会「広域行政・広域合併の課題と展望」は, 筆 者が講師を務めた。主催者に 1 時間程度の意見交換の時間をとるこ とを求めた。参加者からいろいろな意見が出され，筆者も学ぶこと が多かった。従って，講演者の話を一方的に聴かせるだけでなく， ある程度のまとまった時間をとり, 参加者の質問, 意見, 感想を引 き出せるよjに主催者は，工夫すべきである。

B-2.シンポジウム（フォーラム）

(1) 1993 年 10 月 8 日開催の「景観フォーラム」と 1995 年 11 月 30 日開催の「都市景観シンポジウム」で筆者はパネラーを務めた。 これらは基調講演があり, 休㮩後にパネルディスカッションとい う形式であった。終わりの10 分〜15 分がフロアーからの発言(質 問, 意見, 感想)にあてられたが, 3 人〜 5 人が発言して時間切れ となった。参加者は，基本的には基調講演やパネラー同士のやり とりを聴く形式であり，双方向の流れとは言えない。

(2) そこで, 1997 年 2 月 5 日の「まちづくりフォーラム」では, 主 催者と企画段階から話し合い，できるだけ双方向の流れを意識的 に創った。講師 2 人の話を 1 時間, 主催者のスライド上映を 15 分 に抑えて，フロアーのやりとり（質疑応答や意見交換）の時間を 1 時間確保した。主催者は, 当初, 時間が余ることを心配していた が，多くの発言があり，時間を 15 分延長することになった。

(3) 1997 年 11 月 18 日に筆者の研究室が開催した「バリアフリー・シ ンポジウム\&ワークショップ』は，第 1 部がシンポジウムであり, 室蘭市の福祉政策, 室蘭市のバリアフリー対策,バリアフリー住宅, 商業施設のバリアフリー, 交通機関のバリアフリーの説明が各 20 分行った後，質疑と意見交換をした。このシンポジウムは，午後の 第 2 部「事例報告と私の発言」と第 3 部のワークショップを前に参 加者に共通認識を持たせることを意図して企画された。（文献 6)

(4) 鉄道高架事業シンポジウム

東室蘭連続立体交差事業研究会は, 1998 年 11 月 14 日に「室蘭・ 登別の将来と鉄道高架を考える市民フォーラム」を開催した。限 度額立体交差事業に着手した旭川市の取り組みが基調講演で話さ れた。次に「室蘭圈の将来像と鉄道高架」(筆者)，「登別から見た 鉄道高架への期待」(登別市議会議員) 及び「室蘭・登別の連携と 鉄道高架への期待」(室蘭サティ, 登別サティ社長)が，話題を提 供した。休頽後，基調講演者と話題提供者が質問を受ける形で参 
加者と意見交換を行った。参加者は，165 人であった。（文献 7) B-3．タウンウォッチング（見学会）

(1) 景観ウォッチング

景観ウォッチングは, 1993 年 10 月 8 日に室蘭市で開催された 「景観フォーラム」に先だって実施された。市民参加の意義の一つ として,「まちの実情を市民によく理解してもらえる」ことを指摘 したが, 室蘭市内の良い景観や悪い景観を参加者自身が自分の目 で見て知ることやガイドマップに示されていないものを参加者が 再発見したり, 日頃, 意識していないものを見直したりすること は，景観整備を進めるために重要である。

(2) 輪西タウンウォッチング

タウンウォッチングは, 1997 年 10 月 18 日の輪西地区ワーク ショップに先だって実施された。自分たちが生活している場であ る輪西のまちの魅力に触れる機会になった。主催者がウォッチン グのコースやポイント（見どころ）を設定しているが, 後で行わ れたワークショップの意見を見ると設定されたポイント以外にも 参加者が再発見したり, 日頃, 意識していないものを見直したこ とが分かった。

\section{C . 住民主体の参加手法（地区レベル）}

\section{$C-1$. まちづくり委員会・協議会・研究会（行政主導を除く）}

輪西地区活性化推進協議会は, まちなみ整備, 中核施設構想など をまとめている。複数の部会を置いて，地元意見の集約化が図られ ている。先進事例の視察や講師を招いた勉強会等を実施しており, まちづくり研究会という側面も有する。主たるメンバーは, 商業者 (商店街振興組合) と地元住民(町会)である。こうした活動の主体と なる「グループづくり」がまちづくりの第 1 歩となる。また, 室蘭市は 「商業近代化スタートアップ事業」と称して, 活動費を助成している。 $\mathrm{C}-2$. ワークショップ（地区限定型）

(1) 輪西地区ワークショップ

室蘭市輪西地区は，「鉄のまち·室蘭』を象徵する新日鉄の門前 町である。しかし, 1971 年のドルショック以降, 鉄鋼業の人員の 大幅な合理化が進められ，人口減少が激しかった。新日鉄の最後 に残った高炉の存続が決定し, 急激な人口減少に歯止めがかかっ たことは，輪西地区の新しいスタートになった。

高龄化と少子化に伴う人口微減に对応した輪西のまちづくりを 住民参加で進めるためにワークショップを企画した。第 1 回輪西 ワークショップ「まちの健康診断〜早期発見・早期治療で生き生 きしたまちづくり〜」が 1997 年 10 月 17 日に開催され，35名が参 加した。翌 18 日に第 2 回ワークショップ「輸西を歩こう〜私たち のまち・輪西再発見」（タウンウォッチング\&ワークショップ）が 開催され，40名が参加した。全体的に提案型の意見が多く, まち づくりに関する参加意識の高さが見られた。説明会方式に比べて, ワークショップは住民の意見の把握という意味で有効な手法と判 断される。事前にタウンウォッチングを行うことにより, 参加者 が現況や個々の問題点を理解し，輪西のまちづくりの必要性につ いて，共通認識を持って，意見を交わしたことが評価される。初 对面に近い参加者同士が活発に話し合うには，ある程度の共通認 識を持たせることが必要であり，そのための時間や労力を惜しむ べきではない。
輪西地区のワークショップは, 第 7 回まで行われ, 継続性を持っ ていたことと次のステップとして計画づくりにつなげたことか高 く評価される。(文献 8)

(2) 中央地区ワークショップ

中央地区を対象にして実施された空き店舗対策事業の一環とし て消費者と商業者を主たる参加者にしたワークショップを開催し た。はじめに消費者と中央地区の関わり（商業者は自分の商売） を話してもらった。同地区の魅力と問題点が浮かび上がった。小 売店よりも飲食店の方に魅力ある店が多いこと, 閉まった錆びた シャッターがマイナスイメージの原因という指摘が多かった。次 に望ましい中央地区の姿 (将来像)に足りないもの, 最近の変化, 魅力アップに必要なもの，活性化に向けた提案について話し合っ た。「消費者 VS 商業者」という对立の構図は避けられたが, 商店 街の魅力アップを求める消費者と, 後継者問題や新規投資の困難 性を訴える商業者との溝を埋めることはできなかった。(文献 9) $\mathrm{C}-3$. 計画づくり

(1) 1995 年 3 月に「室蘭地域商業近代化計画」を策定するにあたり， 中央地区, 輪西地区, 東地区, 中島地区, 本輪西地区の 5 地区に地区 分科会を設置し, 10 人程度の商業者がメンバーとして参加した。 地区分科会は各々 7 8 回 (合同分科会を含む) 開催された。地区 分科会は総合企画調整分科会で検討した原案を提示し, 商業者等 の意見を聴き, 積み残し部分は各地区に持ち帰って, 決められた期 日までに地元（メンバー以外の商業者等）の意見をまとめて提出 する形で進められた。総合企画調整分科会と地区分科会, 地区分科 会委員の商業者と一般商業者とのフィードバックが重要である。

(2) 中島中央通りまちづくり協定

1995 年 3 月の『室蘭地域商業近代化計画」の第 5 分冊『中島地 区整備計画」の実現をめざして，同年 5 月に設立された「中島地区 まちづくり委員会」の活動を通じて, 中島中央通りの街路拡幅事 業の対象区域に地区計画が適用された。また，地区計画がカバー できない事項については，まちづくり協定が結ばれ，店舗の新築 や建替の建築確認申請の前に「中島街並み形成委員会」のチエッ クを受ける体制ができた。

D．市民主体の参加手法（全市レベル）

D-1. まちづくり委員会・協議会・研究会（行政主導を除く）

(1) 商業近代化推進運営協議会

同協議会は，1995 年 3 月の「室蘭地域商業近代化計画」の完成 を受けて, 同計画の実施を推進する目的で, 同年 4 月設置されたも のである。メンバーには各地区の商業者が加わっている。基本的 には各地区の近代化に向けた動きを互いに把握したり，商店街の 空店舗・空地対策などの共通の課題について協議する場と聿え る。「商業近代化ニュースー進め! 商店街」を季刊(平成 10 年席か ら隔月）で発行している。

(2) 東室蘭連続立体交差事業研究会 研究会は, 基本的に特定の課題（テーマ）について自主的に研 究する組織と言える。蘭東地区は, JR 室蘭本線により, 海側と山 側に分断され，車で鉄道を横断できる場所が 3 箇所だけであるこ と, 策定作業中の室蘭市総合計画に鉄道高架事業を盛り込む意図 から，1997 年 7 月に『東室闌連続立体交差事業研究会』が, 市民 
有志（企業を含む）によって設立された。会合や勉強会を重ね， 総合計画の説明会で鉄道高架事業の扱いについて意見を述べた。 鉄道高架事業に関して，行政は時期尚早という認識であり，研究 会とは認識が異なるので, 研究会の経費は会員から徵収した会費 で賄っている。これは自由な発言を確保するためであるが，行政 側と認識や方針が一致する市民グループの活動については, 助成 措置も考之られる。

$\mathrm{D}-2$ ．ワークショップ (テーマ限定型)

(1) バリアフリーワークショップ

1997 年 11 月 18 日に筆者が開催した『バリアフリー・シンポジ ウム\&ワークショップ」第 3 部のワークショップは, ワークショップ の説明, グループ討論, 各グループの発表及びまとめ(総括)で構 成した。午前の第 1 部のシンポジウムと先進事例のスライドが, 参加者に問題意識や共通認識を持たせる役割を果たした。(文献 10)

(2) 鉄道高架事業ワークショップ

東室蘭連続立体交差事業研究会は，一般市民向けにシンポジウ ムを開催したが，会員の理解と共通認識を深めることを目的とし

て，1999 年 2 月 4 日にワークショップを開催した。室蘭本線によ る市街地分断の問題点, 鉄道高架事業のメリットと実現に向けた課 題及び東室蘭駅周辺地区の将来像について, 活発な意見交換が行わ れた。筆者は企画, 運営, 結果のとりまとめを担当した。(文献 11)
$\mathrm{D}-3$. 計画づくり

1995 年 3 月の「室蘭地域商業近代化計画」は, 室蘭工業大学, 室 蘭商工会議所の共同研究で策定された。地区分科会 $(5$ 地区の商業者 中心）と総合企画調整分科会（各地区代表，行政，会議所，学識経 験者)とのフィードバックを繰り返しながら策定された。(詳細は文 献 12 と文献 13 に示されている。)

\section{4 . 市民参加手法の評価の試みと今後の課題}

$2 の(2) の$ 市民参加手法の評価の視点に沿って, 定性的な評価基準 を次のように設定した。

(1) 幅広い意見を取り込み

幅広い意見を取り込むことができた場合を○，できない場合

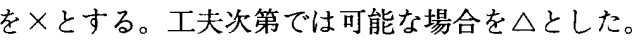

(2) 参加者が限定されているか，否か。

参加者が限定されていない場合を○，参加者が限定される場 合を×とした。また，参加者を限定あるいは意図的に絞り込ん

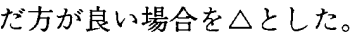

(3) 一方向の流れか, 双方向の流れか。

双方向の場合を○とした。一方向の場合を×とした。双方向

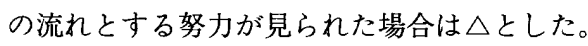

(4) 配布資料や説明が参加者にわかりやすいか。

表 1 市民参加手法の評価結果

\begin{tabular}{|c|c|c|c|c|c|c|c|c|c|c|c|c|c|c|}
\hline \multirow{2}{*}{ 開催主体 } & \multirow{2}{*}{\multicolumn{2}{|c|}{ 各種市民参加手法 }} & \multicolumn{10}{|c|}{ 2.（2）市民参加手法の評価の視点 } & \multirow{2}{*}{$\begin{array}{l}\text { 総合 } \\
\text { 評価 } \\
\end{array}$} & \multirow{2}{*}{ 計画、地区、テーマ等 } \\
\hline & & & (1) & (2) & (3) & (4) & (5) & (6) & (7) & (8) & (9) & (11) & & \\
\hline \multirow[t]{8}{*}{ 行政主体 } & \multicolumn{2}{|l|}{ 公 聴 会 } & $x$ & $x$ & $x$ & $\triangle$ & $x$ & $x$ & $x$ & $x$ & $x$ & $x$ & 1 & 区域区分の見直し \\
\hline & \multirow[t]{3}{*}{ 説 明 会 } & (1) & $x$ & $\times$ & 0 & 0 & $x$ & $x$ & 0 & $\triangle$ & $\mathrm{O}$ & O & 11 & 商業近代化計画の説明 \\
\hline & & (2) & $x$ & $x$ & $\triangle$ & $\triangle$ & $x$ & $x$ & $\triangle$ & $x$ & $x$ & 0 & 5 & 北海道長期計画策定過程 \\
\hline & & (3) & $x$ & $x$ & $\triangle$ & $\triangle$ & $x$ & $x$ & $\triangle$ & $\triangle$ & $x$ & 0 & 6 & 室闌市総合計画策定過程 \\
\hline & \multicolumn{2}{|l|}{ 意見聴取（文書） } & 0 & $\triangle$ & $x$ & - & $x$ & $x$ & - & $\triangle$ & $x$ & 0 & 6 & 室闌市総合計画策定過程 \\
\hline & \multicolumn{2}{|l|}{ ヒアリング } & 0 & $\mathrm{O}$ & $\triangle$ & - & $x$ & $\mathrm{O}$ & $\mathrm{O}$ & $\triangle$ & 0 & 0 & 14 & 商業近代化計画策定過程 \\
\hline & \multicolumn{2}{|l|}{ アンケート調查 } & $\triangle$ & $\mathrm{O}$ & $x$ & $\triangle$ & $x$ & $\triangle$ & - & $x$ & $x$ & 0 & 7 & 消費者動向調查 \\
\hline & \multicolumn{2}{|c|}{ 蕃議会・委員会の公募委員 } & $x$ & $x$ & $\triangle$ & $\triangle$ & 0 & 0 & $\mathrm{O}$ & 0 & $x$ & 0 & 12 & 都市景観市民懇話会 \\
\hline \multirow[t]{7}{*}{ 学習主体 } & \multicolumn{2}{|c|}{ 講 演 会 } & $x$ & $\mathrm{O}$ & $x$ & $\triangle$ & $x$ & $x$ & $\triangle$ & $x$ & 0 & 0 & 8 & 広域行政・広域合併 \\
\hline & \multirow{4}{*}{$\begin{array}{l}\text { フォーラム } \\
\text { シンポジゥム }\end{array}$} & (1) & $x$ & $\mathrm{O}$ & $x$ & $\triangle$ & $x$ & $\times$ & $x$ & $\triangle$ & $x$ & 0 & 6 & 都市景観 \\
\hline & & (2) & 0 & 0 & 0 & $\triangle$ & $x$ & $x$ & 0 & $\triangle$ & 0 & $\mathrm{O}$ & 14 & まちづくり \\
\hline & & (3) & $\triangle$ & $\mathrm{O}$ & $\triangle$ & $\triangle$ & $x$ & $\mathrm{O}$ & $\triangle$ & $\triangle$ & 0 & 0 & 13 & バリアフリー \\
\hline & & (4) & 0 & $\mathrm{O}$ & 0 & $\triangle$ & 0 & 0 & $\triangle$ & $\triangle$ & 0 & 0 & 17 & 鉄道高架事業 \\
\hline & \multirow[t]{2}{*}{ タウンウォッチング } & (1) & - & 0 & - & $\triangle$ & $x$ & - & - & $\triangle$ & $\mathrm{O}$ & 0 & 8 & 都市景観 \\
\hline & & (2) & - & 0 & - & $\triangle$ & $x$ & - & - & $\triangle$ & 0 & 0 & 8 & 輪西地区まちづくり \\
\hline \multirow{5}{*}{$\begin{array}{l}\text { 住民主体 } \\
\text { （地区） }\end{array}$} & \multicolumn{2}{|c|}{ まちづくり委虽会・協議会 } & $\mathrm{O}$ & $\triangle$ & (O) & $\triangle$ & 0 & 0 & 0 & (2) & 0 & 0 & 20 & 輪西地区まちづくり \\
\hline & \multirow{2}{*}{ ワークショップ } & (1) & 0 & $\mathrm{O}$ & O & $\triangle$ & 0 & 0 & O & $\mathrm{O}$ & 0 & $\mathrm{O}$ & 21 & 輪西地区まちづくり \\
\hline & & (2) & () & $\mathrm{O}$ & $\mathrm{O}$ & 0 & 0 & 0 & (O) & 0 & 0 & 0 & 22 & 中央地区まちづくり \\
\hline & \multirow{2}{*}{$\begin{array}{l}\text { 計画づくり } \\
\text { 協定づくり }\end{array}$} & (1) & 0 & $\triangle$ & 0 & $\triangle$ & 0 & O & $\mathrm{O}$ & 0 & $\mathrm{O}$ & 0 & 18 & 商業近代化計画（地区） \\
\hline & & (2) & 0 & 0 & ( & $\triangle$ & (2) & 0 & 0 & 0 & 0 & 0 & 23 & 中島中央通り昿幅整備 \\
\hline \multirow{5}{*}{$\begin{array}{l}\text { 市民主体 } \\
\text { (全市) }\end{array}$} & \multirow{2}{*}{$\begin{array}{l}\text { まちづくり委員会・ } \\
\text { 協議会・研究会 }\end{array}$} & (1) & $\triangle$ & $\triangle$ & 0 & $\triangle$ & 0 & $\mathrm{O}$ & $\triangle$ & $\triangle$ & $\mathrm{O}$ & 0 & 15 & 商業近代化計画の推進 \\
\hline & & (2) & 0 & $\triangle$ & 0 & $\triangle$ & 0 & $\mathrm{O}$ & 0 & (C) & $\mathrm{O}$ & $\mathrm{O}$ & 19 & 鉄道高架事業 \\
\hline & \multirow{2}{*}{ ワークショップ } & (1) & (0) & 0 & (0) & 0 & 0 & 0 & (1) & 0 & 0 & (2) & 24 & バリアフリー \\
\hline & & (2) & 0 & $\triangle$ & (0) & 0 & 0 & $\mathrm{O}$ & (0) & (O) & (0) & (0) & 24 & 鉄道高架事業 \\
\hline & \multicolumn{2}{|l|}{ 計画づくり } & (C) & 0 & (0) & $\triangle$ & (a) & 0 & () & 0 & (0) & (2) & 25 & 商業近代化計画（全体） \\
\hline
\end{tabular}

※同じ参加手法の丸数次は、「3．各種市民参加手法の実態と問題点」のものと一致している。 
配布資料や説明が分かりやすい場合を○，分かりにくい場合

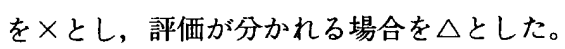

(5) 継続性があるか, 否か。

継続性 (連続性) がある場合を $\mathrm{O}, 1$ 回限り (単発)の場合を $\times$ とした。

(6)出された意見の取り扱いが明確か。

市民等から出された意見の取り扱いが明確な場合を○、明確 でない場合をメとした。

(7) 市民が発言する時間が十分に確保されているか。 意見交換や質疑応答等の時間が 1 時間以上確保している場合 を○, 確保していない場合や確保していても 15 分未満の場合 を×とした。15 分以上で 1 時間未満の場合は $\triangle$ とた。

(8) 能動的な参加か, 受動的な参加か。

能動的な参加の場合を○, 受動的な場合をメとした。能動的

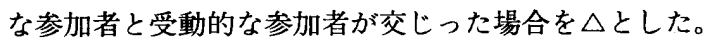

(9) 主催者が市民参加に積極的か, 消極的か。 主催者が市民参加に積極的な場合を $\bigcirc ，$ 消極的な場合を $\times$ と した。

(10) 形式的に行われていないか。 市民参加が実質的な場合を $\bigcirc$, 行政手続きの一部として行わ れる等，市民参加が形骸化している場合を×とした。

(1)から10に共通して, ある参加手法に限って評価が不要な場合や 評価が馴染まない場合は一とした。

また，他の手法に比へてて，前述した「市民参加の意義」に照らし て，特に意義が大きいと思われる場合はのとした。

以上から, 評価の視点ごとに定性的な評価を行った。しかし, 何 らかの形で数值を与えないと, 定量的な評価ができないし, 総合評 価もできない。そこで, 定量的な評価にあたって，各評価の視点の 定性的な評価の@を 3 点, $\bigcirc を 2$ 点, $\triangle$ を 1 点 $\times$ または一を 0 点を与 えて，数量化した。そして，(1)（10)の合計を総合評価とした。

(1)（10)の視点別の評価結果と総合評価の結果を表 1 に示す。

表 1 の評価結果は, 筆者が室蘭市において経験した事例の評価に すぎないが, 行政主体の公聴会や説明会の総合評価の得点が 1 1 11 点と低く, 逆に, 住民主体または市民主体の参加手法（特にワーク ショップや計画づくク)の総合評価の得点が 15 25 点と高く, 妥当 な結果が得られたと考える。また, 今後, 都市計画においては, 実 質的な市民参加（地区が限定された場合は住民参加）をさらに進め る必要性が高いことから, (1)から(10)の評価の視点は, 概ね妥当なも のと考える。従って, 行政が行う、各種計画や各種事業においても, 市民主体や住民主体の参加手法を積極的に採り入れるべきである。

表 1 から, 説明会(1)の 11 点と説明会(2)の 5 点, あるいはフォーラ ム(1)の 6 点とフォーラム(4)の 17 点のように同じ手法であっても,や ク方次第で評価が異なることを考えれば，やり方の適切さを評価に 反映させるように評価の視点（評価項目）の細分化させることが， 今後の課題である。また, 初めての試みであることから, 本研究で は各評価の視点を全て同ウエイトと仮定して総合評価を行ったが, 本来的には各評価の視点（1（10)）の重要度に応じたウエイトづけ を行う必要があり，これも今後の課題である。

本研究では, 筆者が参加した 25 の事例について評価を試みたが, (a) 市全体の計画への参加か, 地区の計画への参加か, (b) 調査, 構 想，計画，事業のいずれの段階における参加か，(c) 具体的な規制や 事業化による利害関係が生じることへの参加か, などを考慮して, 評価の視点を見直していくことも，今後の課題である。

一般的に計画づくり, 協定づくり, 条例づくりは, いくつかの参 加手法を組み合わせて進められることから, 市民参加手法の組合せ の評価方法について検討することも，今後の課題である。

さらには, 具体的なまちづくり, 規制や事業を前提として, 計画 づくク, 協定づくク, 条例づくりが行われることから, そこで用い られる市民参加手法は, まちづくりの進捗状況, 規制の実施, 事業 化への効果の面からも評価できるようにしていくことも, 今後の課 題である。

\section{《参考文献・参考资料》}

1）浦口醇二, 大坂谷吉行 住民参加に上る景観調查・計画の訪み 「都市計画」第 138 号 pp.95 100 1985.10

2）吉村輝彦，原科幸彦 都市計画マスタープラン策定システムの デザインへの市民参加に関する研究〜川崎市宮前区を事例とし て〜 都市計画論文集第 31 号 pp.319 324 1996.11

3) 村木美貴, 中井検裕 都市計画マスタープランの地域別市街地 像策定のためのまちづくり協議会の役割に関する一考察〜東京 都心区に着目して〜 都市計画論文集第 32 号 pp.247 252 1997.11

4）錦澤滋雄, 吉村輝彦, 原科幸彦 都市計画マスタープラン策定 におけるまちづくりワークショップの現状分析〜鎌倉市を事例 として〜 都市計画論文集第 32 号 pp.253〜258 1997.11

5）梖枝潤一, 篠崎道彦, 打林国雄 環境シミュレーションシステ ムを用いた住民参加の街づくり〜東京都足立区西新井大師陆前 地区をケースとして〜 都市計画論文集第 31 号 pp.199 204 1996.11

6) 大坂谷吉行, 川端智浩, 島 遵 地方中小都市のバリアフリー の現状と改善方法の提案〜室蘭市, 伊達市, 登別市における4一 ススタディ (財) 第一住宅建設協会 1998.4

7）東室蘭連続立体交差事業研究会 同会会報第 2 号 1998.12

8）輪西地区活性化推進協議会 子孫に残したい...輪西の将来を 描く 〜輪西地区の活性化に向けた提言〜 (全 118 頁) 1998.3

9）室蘭商工会議所 室蘭地域商店街活性化先進事業（空き店舗对 策）報告書〈本編〉，〈資料編〉 1999.3

10）前掲の文献 6

11）東室蔯連続立体交差事業研究会 同会会報第 3 号 1999.3

12）室藩商工会議所 室蘭地域商業近代化計画報告書（全 6 冊：室 蘭市の商業ビジョン, 中央地区整備計画, 輪西地区整備計画; 東 地区整備計画, 中島地区整備計画, 本輪西地区整備計画) 1995.3

13）大坂谷吉行 室蘭地域商業近代化計画をめぐる課題 都市計画 論文集第 32 号 pp.199 204 1997.11

14）室蘭市 第 4 次室萰市総合計画 1998.3

15）室蘭市 第 4 次室闌市総合計画の基本構想〈案〉 基本構想説明 会資料 1997.5

16）室蘭市 第 4 次室蘭市総合計画の基本計画〈案〉基本計画説明 会資料 1997.10

[2000年 4 月20日原稆受理 2000 年 7 月26日採用決定］ 